\title{
Ajdukiewicz on skepticism
}

\author{
Renata Ziemińska ${ }^{1}$
}

Published online: 16 February 2016

(C) The Author(s) 2016. This article is published with open access at Springerlink.com

\begin{abstract}
Kazimierz Ajdukiewicz understands skepticism as the thesis that there is no criterion of truth and that the justification of any thesis is impossible. According to Ajdukiewicz, a typical skeptic confuses two levels of justification: the first order justification of a proposition $s$ and the second order justification of the proposition that $s$ is justified. However, the first-order justification is possible without secondorder justification. This argument presented by Ajdukiewicz in 1923 heralded the epistemic externalism concerning justification developed by Alvin Goldman in 1980 and the externalist response to skepticism developed by F. Dretske and M. Williams. They all suggested weakening the traditional concept of justification and concluded that if we accept the possibility of justification without self-justification, the skeptical regress is blocked. However, such a response to skepticism is dependent on the externalist notion of justification. Ajdukiewicz had opportunity to use the stronger argument from self-refutation, but he underestimated its utility. The other side of Ajdukiewicz's relation to skepticism is his radical conventionalism that presupposes some moderate form of skepticism in a broad sense. The article is an attempt to determine what kind of skepticism Ajdukiewicz accepted and what kind he rejected. The conclusion is that Ajdukiewicz is an anti-skeptical fallibilist.
\end{abstract}

Keywords Ajdukiewicz $\cdot$ Skepticism · Justification · Externalism · Self-refutation · Fallibilism

Kazimierz Ajdukiewicz was a member of the Lvov-Warsaw School. The problem of skepticism was developed there both in historical and epistemological aspects. For instance, Władysław Tatarkiewicz accepted Franz Brentano’s opinion that

Renata Ziemińska

renata.zieminska@whus.pl;

http://www.zieminska.whus.pl

1 University of Szczecin, Szczecin, Poland 
"skepticism is one of four phases cyclically repeated in the history of philosophy" (Dambska 1958, 11), namely the phase following that of systems and schools (the cycles repeated in ancient, medieval and modern times). Izydora Dạmbska opposed this thesis and claimed that skepticism parallels the phase of systems. According to her, skeptical doubts and criticism are inseparable companions of every theoretical creativity (Dạmbska 1948a, 85; Ziemińska 2013a, 364). Dąmbska translated Against the Logicians by Sextus Empiricus into Polish, and wrote a book about French skepticism in the sixteenth and seventeenth centuries (Dąmbska 1958). As far as the epistemological aspect of skepticism is considered, Dạmbska claimed that skepticism is a coherent and well justified view. She wrote: "theoretical skepticism has not been rebutted in any satisfactory way until now (...) and in the domain of scientific knowledge this view has prevailed." (Dąmbska 1948a, 82) In her opinion contemporary philosophers usually reject "normative skepticism while accepting the critique of knowledge by theoretical skepticism, even continuing and deepening it." (Dạmbska 1948b, 246).

Kazimierz Ajdukiewicz (1890-1963) evaluates skepticism in a different way and openly claims that skepticism does not deserve any rational acceptance. He points, like later externalists, to the mistake of blurring two levels of justification and to the questionable presupposition that every justification requires the justification of its own justification. However, Ajdukiewicz accepts radical conventionalism that can be interpreted as a form of moderate skepticism or fallibilism. I am going to answer the question in what sense is skepticism rejected by Ajdukiewicz, and whether his anti-skeptical strategy is effective.

\section{Externalist response to skepticism}

Ajdukiewicz openly rejects skepticism in his anti-skeptical argument. He defines skepticism as the desperate thesis that "we can know nothing, that is to say that we have no justifiable knowledge about anything" (Ajdukiewicz 1973, 18, see 19). The source of such skepticism is according to Ajdukiewicz the lack of a criterion of truth as a "final resort in deciding about the justification of our beliefs." (1985a, 11).

In his textbook Problems and Theories of Philosophy Ajdukiewicz presents the skeptical argument against the possibility of a truth criterion. He refers to ancient Agrippa's trilemma showing that every attempt to justify a thesis about such a criterion leads to infinite regression in the process of justification (premises used in the justification need further justification and the additional justification requires still further premises that we should justify and so on in infinitum). "In order to know whether our criterion is a trustworthy one we should have to apply another criterion which again would have to be examined critically before we could trust it, etc. ad infinitum" (Ajdukiewicz 1973, 19). Infinite regression can be avoided only at the cost of a vicious circle (reciprocity in the justification of our premises) or a groundless hypothesis (taking premises in some arbitrary way). Every choice in the trilemma is fatal to rational justification. A skeptic concludes: "it is not possible, then, to find a way which would lead us to justifiable knowledge about anything." (Ajdukiewicz 1973, 19). 
After presenting this argument, Ajdukiewicz points to some questionable but tacitly accepted presuppositions. "The skeptics assert that in order to gain justified knowledge it must be arrived at by applying a criterion about which we should know beforehand that it is trustworthy." (Ajdukiewicz 1973, 20) But, according to Ajdukiewicz "in order to justify an assertion it is sufficient to arrive at it by applying a trustworthy criterion and we do not have to know also that the criterion applied is trustworthy" (Ajdukiewicz 1973, 20). ${ }^{1}$ Here is where the skeptics' mistake lies, Ajdukiewicz writes: "It is one thing to justify an assertion and another to know that one has done so. It is one thing to do something well and it is another to know that one has done so." (Ajdukiewicz 1973, 21).

In the paper "O stosowaniu kryterium prawdy" [On the application of the truth criterion] he claims that a skeptic confuses "the possibility of valid assertion that $S$ is validly asserted and just valid assertion of $S$." (Ajdukiewicz 1985a, 13) A skeptic confuses two levels of justification: the justification of proposition $S$ with the justification of the proposition that $S$ is justified. A skeptical position is the excessive demand for every justification to deliver at the same time the guarantee of its truth. It is the demand that every justification should be self-justifying. Ajdukiewicz rightly observes that when we have questioned this demand, the skeptical conclusion that "justification of any assertion whatsoever requires an infinite number of steps of reasoning which can never be completed" (Ajdukiewicz 1973, 21) ${ }^{2}$ collapses.

Writing about Ajdukiewicz's refutation of skepticism, Jan Woleński presents the main argument as the demand to distinguish between two levels of knowledge (first order knowledge and second order knowledge). "Perhaps we could say that unrestricted claims on knowledge are the source of problems raised by skepticism in the exactly same manner as unrestricted quantification over languages leads to semantic paradoxes." (Woleński 1995, 356) The main fault of skeptical proof is the confusion between the first and second order of justification: the justification of a proposition and the justification that this justification is a valid justification. "The sceptic confuses here the possibility of valid assertion that a proposition is validly asserted with the assertion of its validity." (Woleński 1995, 355) This distinction has an anti-skeptical effect because it questions the assumption that knowledge should always be accompanied by knowledge about the validity of this knowledge and that every justification should be self-justified.

After the externalist turn in 1980, contemporary epistemology enriched its vocabulary by the pair of opposite concepts externalism-internalism, which is very useful to describe this argument. Ajdukiewicz' s anti-skeptical argument can be called externalist. The externalist response to skepticism presupposes the distinction

\footnotetext{
${ }^{1}$ As Adam Nowaczyk shows, Ajdukiewicz in many texts remarked that valid justification requires applying proper rules but it does not necessarily require having to know additionally that the rules are proper. "To deduce sentences from one another, one need not prove that one is proceeding by infallible rules. It is enough simply to proceed according to them." (Ajdukiewicz 1960, 216).

2 A similar strategy is presented in the paper Sceptycyzm a kryterium prawdy [Skepticism and the criterion of truth] by Andrzej Wisniewski. "Arguing on the ground of accepted premises, we just use the premises and there is no necessity to annex to them in the higher order language the statement about the conditions for validity of premises and conditions for proper inferences" (Wiśniewski 1992, 186). According to Wisniewski, when we distinguish different language orders, the level of premises and the level of reasoning, we can avoid the skeptical regress in infinitum.
} 
between first and second order knowledge. Before presenting Ajdukiewicz as externalist, let us see how the discussion of his position was carried on in Poland without the concept of externalism.

Ajdukiewicz's solution to skepticism was inconsistent with the traditional understanding of justification. Traditionally, justification is worthless if we have no knowledge about the validity of the justification. Skeptics exploited the idea that one has fully rational knowledge when one has the second order knowledge (knowledge about knowledge). And fully rational justification is one that is known to be plausible. Omitting the requirement and accepting knowledge without second order knowledge and justification without second order justification radical weakened the rationality requirement. That is why Ajdukiewicz became the target of strong objections formulated by representatives of phenomenological epistemology, that was prominent in the mid-twentieth century, for instance by Antoni Stępień.

Stępien undertook the discussion with Ajdukiewicz even though he shared the negative evaluation of skepticism. According to Stępien the skeptical thesis has several presuppositions that we need not accept. Two of them are as follows:

1. "If we apply some criterion, we should resolve the problem of its existence and value"

2. “Every criterion is something external to its object.” (Stępień 1966, 95)

Ajdukiewicz questions presupposition (1), but Stępień writes that (1) is "necessary to accept" (Stępień 1966, 95). Stępień is convinced, like contemporary internalists, that factors justifying beliefs must be internal, that is, introspectively accessible to the subject of the belief (Ziemińska 2002, 287). Otherwise they are not justifying factors. Stępien questions presupposition (2). According to him, the criterion of truth can be an internal feature of the cognition which is evaluated as referring to its truth. It is standpoint typical for phenomenological epistemology, as represented by Roman Ingarden.

Roman Ingarden defends the theory of durchleben as the kind of pre-introspective self-consciousness that is part of every cognitive act informing about the act and its value. Skeptical argumentation presupposes that "to get to know some cognition we need another act of cognition." (Ingarden 1971, 365) Indubitable pre-introspective self-consciousness, according to Ingarden, stops all kinds of petitio principii, viz., regress in infinitum, circularity, and groundless assertion. We must observe that such an internal criterion of truth belonging to pre-introspective self-consciousness is prone to the charge of being arbitrary. There is a problem with the distinction between pre-introspective self-consciousness and the ordinary reflection that has no guarantee of being true (Ziemińska 1993, 85).

The discussion between Ajdukiewicz and Stepień in the 60s anticipated contemporary discussion between externalists and internalists. Ajdukiewicz's position anticipated externalism in the theory of justification and an externalist response to skepticism. Externalism in the theory of justification is the thesis that justifying factors can be cognitively inaccesible to the believer whose belief is to be evaluated. In this sense they can be external. The believer does not need to know that her belief is justified when the belief is justified. This kind of externalism was 
defended by Alvin Goldman. The most influential wording of such a view is process reliabilism in Epistemology and Cognition (Goldman 1986): justification is the function of the global reliability of the process that produced the belief. Reliability is the propensity of a process to produce true beliefs at least $50 \%$ of the time (Ziemińska 2002, 292). Confronted by many objections (how to evaluate the objective reliability of a process?) Goldman modified his process reliabilism to aretic reliabilism. Objective reliability is replaced by what is taken as reliable on the list of cognitive processes deserving to be called intellectually virtuous (Goldman 1992). This is a specific concession to internalism. However, Goldman speaks not about the justifying factors being accessible to individual subject but to the community of experts entitled to construe the list of intellectually virtuous processes. "The opinion of experts in some community" when we have no access to objective reliability, is according to Goldman the best way to formulate externalism in the theory of justification (Ziemińska 2002, 203).

We can find similar remarks in Ajdukiewicz in his search for a response to skepticism. What is more interesting, Ajdukiewicz's views on the justification of scientific statements come close to Goldman's later aretic reliabilism (referring also to C.S. Peirce). According to Ajdukiewicz, former controversies among scholars concerning the sufficient justification of certain theses have over the course of time been resolved by the community of experts (Ajdukiewicz 1985b, 376). It seems that both Ajdukiewicz and Goldman were inspired by Peirce's idea of a consensual theory of truth as a common opinion among investigators. "The opinion which is fated to be ultimately agreed to by all who investigate is what we mean by the truth." (Peirce 1931-58, CP 5.407).

The idea of externalism about knowledge and justification has been applied to the problem of skepticism. Fred Dretske and Michael Williams questioned the principle of knowledge transparency (one cannot know without knowing that s/he knows). According to them, first order knowledge does not require second order knowledge. In this context, the skeptical demand that for every case of knowledge there be proof of knowledge, is groundless. Externalists changed the concept of knowledge and emphasized that knowledge can exist without proof (Ziemińska 2002, 305-306). Similar conceptual change was suggested for justification.

Dretske, in his theory of knowledge as the flow of information, pointed out that we know by perception that something is moving while having no knowledge that our senses, eyes, are working properly. The proper functioning of our senses is the channel that is tacitly presupposed in perception, but it does not need to be known (Dretske 1981, 123). A skeptic wrongly assumes that a signal cannot carry some information if it carries no information about the channel of this information. Dretske emphasizes that this skeptical assumption is inconsistent with the conditions governing the circulation of information in nature. In nature, information channels are usually tacitly presupposed with no harm to the flow of information.

It is worth observing that externalism is not able to falsify the skeptical thesis (to exclude skeptical hypotheses). It can only question the skeptical argument by pointing to the internalist presuppositions that can be replaced by externalist ones. Skepticism in its typical variety appears only in the background of the internalist assumption that, if I do not know how I know, I do not know at all. Externalists 
allow that I can know even when I do not know that it is knowledge. An example of such knowledge is that of a small infant who knows how to suckle. Similarly, we can have knowledge about the world even if we cannot respond to skeptical demand to prove that it is knowledge.

The history of the discussion between externalism and internalism suggests that the externalist response to skepticism is effective at the cost of changing the concept of knowledge and justification. Instead of traditional concepts we should accept that knowledge is the state of having information without any further conditions holding of the subject and that justification slips out of the subject's control and approximates to truth. Contemporary internalists, for instance Roderick Chisholm or Laurence Bonjour, formulate the objection that externalists are not able to discuss the traditional problem of skepticism as it appears from the perspective of data accessible to the subject. According to them externalism has no solution to skeptical doubts and tries instead to avoid the problem.

Recently the dominant attitude is that any adequate theory of justification should incorporate both internalist and externalist justifying factors (Williams 2001, 147). If we accept this picture, then Ajdukiewicz's response to skepticism turns out to be one-sided and ceases to be sufficient. However, Ajdukiewicz had a more universal anti-skeptical strategy at his disposal.

\section{Rejecting the counter-argument by self-refutation}

Ajdukiewicz chose the strategy to change the skeptical concept of justification rather than to discuss with the skeptics using their conceptual presumptions. It is enough to reject this strong concept of justification in order to undermine the skeptical argument and thesis. After the change, Ajdukiewicz replaces the skeptical thesis with a fallibilistic thesis (we have no justification with a guarantee of its being true, but we have weaker form of justification). Had Ajdukiewicz undertaken a discussion with skepticism on the ground of its strong concept of justification, he would have had to show either that the skeptical thesis is self-refuting or that it is unjustified. The former is the case as soon as we try to accept a skeptical thesis (there is no justified thesis), however weakly asserted, because the assertion (as speech act) of the thesis contradicts the content of the thesis. The act of assertion presupposes that we accept as justified what we assert. The latter is the case as soon as skeptics say that they do not accept their own thesis at all, in which case on what grounds are they skeptics at all, and why we should take the skeptical position as something deserving serious attention?

In my view, Ajdukiewicz's discussion of the skeptical thesis that "we have no justifiable knowledge about anything" did not exploit properly the counterargument by self-refutation (accepting the skeptical thesis leads to internal contradiction). He presents the argument as follows: "On the one hand, by accepting the sceptics' thesis we should assert that nothing can be justified; on the other hand, however, by accepting that the sceptics' reasoning justifies their thesis, we should admit, against the sceptics' thesis, that something can be justified (namely at least the sceptics' thesis itself)" (Ajdukiewicz 1973, 20). 
According to Ajdukiewicz, this argument is not effective because skeptics can surmount their own philosophical position (put it in doubt). Ajdukiewicz writes about an ancient way to avoid self-refutation by the non-assertion strategy (Ajdukiewicz 1973, 20), which can be interpreted as a weak assertion or no assertion at all. In Gtówne kierunki filozofii [Main Currents of Philosophy in Fragments of Their Classical Representatives] he writes that ancient skeptics threatened by the charge of contradiction refrained from any opinion (Ajdukiewicz 2011, 38-39), "in principle refrain from stating anything" (Ajdukiewicz 2011, 90, note 223). As we read in Sextus Empiricus' books, skeptics declare: we do not "affirm that things certainly are just as we say they are: rather, we report descriptively on each item according to how it appears to us at the time" (Sextus 2000, PH 1.4; see Ajdukiewicz 2011, 90). The skeptical thesis about the impossibility of justifying knowledge is just such a thought, which is not taken as being true.

Ajdukiewicz, like Dambska, accepts as sufficient this explanation given by Sextus Empiricus. He claims that a skeptic can effectively avoid the self-refutation charge. It is noteworthy that Ajdukiewicz refers to Greek sources, translates the proper passage from Sextus' book, and puts it in his anthology Gtówne kierunki filozofi [Main Currents of Philosophy in Fragments of Their Classical Representatives] (Ajdukiewicz 2011, 89-94). Ajdukiewicz is not alone in interpreting ancient skepticism this way. David Hume as well claimed that skepticism is too serious a position to be rebutted by the charge of inconsistency. Skepticism points out the uncertainty of our beliefs about the world, and this problem remains even if we attack skepticism with the charge of self-refutation.

In my view this argument is effective only in case of local skepticism and the kind of traditional skepticism that today is called fallibilism. However these moderate forms of skepticism are not a serious challenge for the theory of knowledge and justification. Ajdukiewicz does not discuss fallibilism, because he himself takes the fallibilist line. He does not require certainty for knowledge and he does not require guarantee of truth for justification.

When Ajdukiewicz engages with skepticism, he examines the thesis of global skepticism with determinate content (namely the thesis that the justification of any thesis is impossible). Ajdukiewicz does not discuss the attitude of doubt (for instance, the attitude of Sextus Empiricus or David Hume) that would open opportunity to avoid any assertion. He examines the particular thesis (it is typical of contemporary skepticism). And he does not analyze the pragmatic conditions for the possibility of asserting the thesis as a speech act.

However, when we take into consideration the thesis that "we have no justifiable knowledge about anything" (Ajdukiewicz 1973, 18), the thesis can be interpreted as pragmatically inconsistent. Even if we use the concept of knowledge without certainty, allowing doubts, the assertion of the skeptical thesis presupposes that the person asserting it takes the thesis as true. Taking as true is the condition of the weakest assertion. If this taking is rational and deserves a serious evaluation, it should be grounded on some reasons. However, having reasons for this thesis, however hesitant they may be, contradicts the content of the thesis. The act of assertion of this thesis presupposes having reasons, but the content of the assertion 
excludes the existence of any reasons. So, the content of the act contradicts its tacit presupposition. It is not an open contradiction but one referring to tacit presuppositions of the speech act in which the thesis is stated. It is the contradiction between what is openly stated and what is tacitly presupposed. Finally, it is the contradiction between two propositions one of which is a hidden tacit assumption. A skeptic asserting this thesis has two options: withdraw the speech act or accept that the speech act is pragmatically inconsistent. (Ziemińska 2013b, 84).

Woleński (1995) analyses Ajdukiewicz's response to skepticism as the thesis "Everything is false". The response occurs in the note to the Sextus' text (in Ajdukiewicz 2011, 91). It is the thesis traditionally attributed to Xeniades of Corinth. Sextus discussed it as the counterbalance to positive theories of truth on the way to suspending judgment on the issue of a criterion of truth. Xeniades' thesis is taken as the model example of a self-refuting thesis (Castagnoli 2010, 13). Ajdukiewicz claims that even skepticism of this kind is not falsified by self-refutation. To achieve this, one needs to presuppose the principle of Excluded Middle: "If one of two contradictory propositions is false, then the second is true" (Ajdukiewicz 2011, 91, note 231). However, the principle is not accepted by the skeptics along with all the other principles and theses. Woleński takes it as Ajdukiewicz's main argument against using the self-refutation strategy in examining skepticism. "Ajdukiewicz does not agree with a common view that skepticism is self-refutable. He points out that this argument against skepticism assumes the validity of the principle of the excluded middle, whereas the skeptic can simple reject the principle" (Woleński 1995, 353).

One can look at the thesis from the point of view of logical pragmatics and speech act theory. When skeptics assert "Everything is false", they tacitly presuppose that their assertion is true. There is a contradiction between this tacit presupposition and the content of the assertion. They presuppose that at least one assertion is true, but claim that none is true. However, this contradiction is not a falsification of either of the two contradictory theses. As Castagnoli (2010, 355) observed, the thesis "everything is false" can still be true, even if there is no pragmatic means to assert it without contradiction. One can avoid the contradiction by drawing back from the act of assertion, without evaluating the sides as true or false. In this sense self-refutation does not prove that skepticism is false. This analysis of self-refutation is another explanation of the fact that, in this case, the Principle of Excluded Middle does not have to be valid.

Even if self-refutation does not disprove skepticism, it is a serious pragmatic argument that dissents from the skeptical thesis. The self-refutation argument or the pragmatic inconsistency argument seems to be less controversial than the externalist response with doubtful externalist assumptions.

\section{Is radical conventionalism a kind of skepticism?}

Izydora Dạmbska once asked whether conventionalism (for instance in the style of Ajdukiewicz 1934) is a kind of epistemological relativism, and her answer was negative. She added that conventionalism even provides reasons against the thesis that truth is relative (Dambska 1938, 332). "Relativism is a thesis about the truth- 
value of propositions, while conventionalism is a thesis about the necessary conditions for their adjudication [...]. Conventionalism is just the thesis that there are many world-pictures." (Dạmbska 1938, 331). Briefly, that there are many worldpictures (the ways we see the world) does not contradict the existence of one objective truth (the way the world $i s$ ), and revealing the conventional elements in the meaning of propositions explains why it seems to us that truth is relative. On the ground of conventionalism we cannot claim that truth is relative, because we can claim nothing without conventions.

Dambska in accordance with the tradition of the Lvov-Warsaw School, in particular the text by her master Kazimierz Twardowski "On So-Called Relative Truths," understood relativism as the radical epistemological rejection of the Principle of Non-Contradiction. She omitted moderate versions of relativism that, like conventionalism, are acceptable (for instance, cognitive relativism, the thesis that the way we get to know the world depends on our psychophysical condition, our point of view or cultural context). Both conceptual conventions and circumstances attending assertion determine the meaning of our statements, and the meaning of a statement is the basis for further establishing its logical value. But we can claim that when a statement has an established meaning, its logical value depends only on the world. This is how Ajdukiewicz and Dambska could accept both radical conventionalism and the objective concept of truth (rejecting relativism about truth).

One can ask a similar question with regard to skepticism. Is Ajdukiewicz's radical conventionalism a kind of skepticism? And how can we combine it with his refutation of skepticism? Ajdukiewicz's radical conventionalism ${ }^{3}$ is the thesis that linguistic conventions determine the acceptance or rejection of even simple empirical reports. As Jerzy Giedymin writes, the conventional elements in our knowledge are not isolated conventions but rather close-knit conceptual systems of languages (Giedymin 1978, XXVII). "On this point our view is close to the Copernican idea of Kant, according to which knowledge of experience depends not only on the material of experience but also on the apparatus of categories used in working up the material." (Ajdukiewicz 1978, 86) As a result our world-picture is dependent on the conceptual apparatus and changes in the latter induce changes in the former. "Of all the judgements which we accept and which accordingly constitute our entire world-picture, none is unambiguously determined by experiential data, every one of them depends on the conceptual apparatus we choose to use in representing experiential data." (Ajdukiewicz 1978, 67).

Being a radical conventionalist Ajdukiewicz avoids using the predicate of objective truth, justifying this with reference to semantic antinomies and pointing to the transparency of the predicate of objective truth. "If someone states with conviction the sentence 'The Vistula is a river', then additionally he is ready to state with conviction the sentence " $<$ The Vistula is a river $>$ is true in my language", (Ajdukiewicz 1978, 82). He writes about "truth in my language", "accepting as true". The problem of the truth-value of different world-pictures is closed within the boundaries of particular languages, without the possibility to adjudicate the truthvalue for statements untranslatable in one's own language. Because of the mediation

\footnotetext{
3 The late Ajdukiewicz became a proponent of radical empiricism.
} 
of conventions the concept of objective truth is treated as referring to something inaccessible. Ajdukiewicz excludes the possibility of infallible recognition of truth (Ajdukiewicz 1978, 82). Even scientific theories are fallible.

Views like these support one kind of moderate skepticism that has recently been called fallibilism. Ajdukiewicz's view about truth enclosed in language that cannot be adjudicated outside the language is similar to Sextus Empiricus' discourse about his own impressions. Uncertainty of knowledge is similar to contemporary Cartesian skepticism represented by Unger (1975). Ajdukiewicz however does not claim, as does Sextus, that one should not accept anything as true, nor does he claim, as does Peter Unger, that knowledge does not exist because it requires certainty. That is why Ajdukiewicz is not a skeptic when we use our contemporary vocabulary. He is a fallibilist. And he is an anti-skeptical fallibilist because he presents an anti-skeptical argument. He claims that knowledge is fallible, but he does not claim that it does not exist. He is a conventionalist and, later, an empiricist but he remains all the while a fallibilist.

\section{Anti-skeptical fallibilism}

Contemporary skepticism and fallibilism differ in regard to their concepts of knowledge. Both positions emphasize the absence of certainty. Peter Unger, a contemporary skeptic, assumes that to know is to know with certainty, and so knowledge does not exist. Fallibilists assume that knowledge does not require certainty, and so it is obvious that knowledge exists (Peirce 1931-58, CP 1.171). The difference is conceptual and emotional. It is easy to change the meaning of the word skepticism (as the claim that there is no certainty) and fallibilism would be a kind of moderate skepticism.

American pragmatists, especially Ch. S. Peirce and W. James, combined an antiskeptical stance with a fallibilism. Thereafter there has been opposition between these two positions. In ancient and modern times they were not distinguished. On the one side, Ch. S. Peirce and W. James emphasized the lack of certainty and fallibility of all our beliefs, and on the other side they had no reason to question the existence of knowledge (Hookway 2008, 326). On the contrary, pragmatists were hostile towards skepticism as the position that, across the centuries, was at odds with activity and the requirements of life. Skepticism was pessimistic and pragmatism was optimistic. For pragmatists any radical skepticism was dangerous because it blocked active inquiry and other kinds of activity (Peirce 1931-58, CP 1.153).

The pragmatic turn changed the meaning of our contemporary concept of knowledge. David Hume had the same reasons for doubt as W. V. Quine, but Hume considered himself a moderate skeptic while Quine as only a fallibilist. "On the doctrinal side, I do not see that we are further along today then where Hume left us. The Humean predicament is the human predicament" (Quine 1969, 72). In contemporary vocabulary, skepticism based on Hume's skeptical arguments is called fallibilism. Hume accepted the Cartesian concept of infallible knowledge, and a contemporary fallibilist assumes that knowledge can turn out to be false.

If we accept the distinction between fallibilism (there is knowledge but it is not infallible) and skepticism (there is neither knowledge nor rational justification), we 
have two conclusions. (1) Ajdukiewicz is not a skeptic at all, but (2) he does not appreciate the self-refutation argument. The argument is not addressed to a fallibilist (they can easily avoid it) but to a skeptic claiming the thesis that rational knowledge does not exist. Fallibilist thesis can be asserted without pragmatic inconsistency, but the skeptical thesis cannot be asserted without pragmatic inconsistency. For a skeptic the concept of justification, reason, assertion includes strong requirements. If I assert that there is no justified knowledge, I assume tacitly that I am right and at the same time I claim that there are no reasons. Self-refutation is not falsification, it only points to the contradiction in the act of assertion. Contradiction can be avoided by the withdrawal from the act of assertion. In this case it is retreat from skepticism. Ajdukiewicz accepted Sextus Empiricus' trick too hastily: do not assert the skeptical thesis but remain a skeptic. ${ }^{4}$

Open Access This article is distributed under the terms of the Creative Commons Attribution 4.0 International License (http://creativecommons.org/licenses/by/4.0/), which permits unrestricted use, distribution, and reproduction in any medium, provided you give appropriate credit to the original author(s) and the source, provide a link to the Creative Commons license, and indicate if changes were made.

\section{References}

Ajdukiewicz, K. (1960). The axiomatic systems from the methodological point of view. Studia Logica, 9 , 205-220.

Ajdukiewicz, K. (1973). Problems and theories of philosophy (H. Skolimowski \& A. Quinton, Trans.). Cambridge: Cambridge University Press. [first edition in Polish 1949].

Ajdukiewicz, K. (1978) [1934]. The world-picture and the conceptual apparatus (J. Wilkinson, Trans.). In J. Giedymin (Ed.), The scientific world-perspective and other essays (1931-1963), pp. 67-89. Dordrecht: Reidel.

Ajdukiewicz, K. (1985a) [1923a]. O stosowaniu kryterium prawdy [On the Application of the Truth Criterion]. In K. Ajdukiewicz (Ed.), Jezyk i poznanie, vol. 1, pp. 11-13. Warszawa: PWN.

Ajdukiewicz, K. (1985b) [1963]. Zagadnienie uzasadniania [The Problem of Justification]. In K. Ajdukiewicz (Ed.), Jezyk i poznanie, vol. 2, pp. 374-383. Warszawa: PWN.

Ajdukiewicz, K. (2011) [1923b]. In J. Jadacki (Ed.), Główne kierunki filozofii w wyjatkach z dziet ich klasycznych przedstawicieli [Main Currents of Philosophy in Fragments of Their Classical Representatives]. Warszawa: Semper.

Castagnoli, L. (2010). Ancient self-refutation. The logic and history of the self-refutation argument from Democritus to Augustine. Cambridge: Cambridge University Press.

Dąmbska, I. (1938). Konwencjonalizm a relatywizm [Conventionalism and Relativism]. Kwartalnik Filozoficzny, 15, 328-337.

Dąmbska, I. (1948a). O rodzajach sceptycyzmu [Types of Skepticism]. Kwartalnik Filozoficzny, 17(1-2), 79-86.

Dąmbska, I. (1948b). Sceptycyzm i agnostycyzm we współczesnej epistemologii [Skepticism and Agnosticism in Contemporary Epistemology]. Sprawozdania Poznańskiego Towarzystwa Przyjaciót Nauk, 2, 245-247.

Dąmbska, I. (1958). Sceptycyzm francuski XVI i XVII wieku [French Skepticism in the 16th and 17th Century] Toruń. Towarzystwo Naukowe w Toruniu.

Dretske, F. I. (1981). Knowledge and the flow of information. Cambridge, MA: Bradford Book.

Giedymin, J. (1978). Editor's introduction: Radical conventionalism, its background and evolution: Poincaré, LeRoy, Ajdukiewicz. In K. Ajdukiewicz (Ed.), The Scientific World-Perspective and other Essays (1931-1963), ed. by J. Giedymin, pp. XIX-LIII. Dordrecht: Reidel.

\footnotetext{
4 This is a modified version of a paper published in Polish: Ajdukiewicza eksternalistyczna odpowiedź na sceptycyzm. Przeglad Filozoficzny 2013 no. 4, 399-411.
} 
Goldman, A. I. (1980). The internalist conception of justification. Midwest Studies in Philosophy, 5, 27-51.

Goldman, A. I. (1986). Epistemology and cognition. Cambridge, MA: Harvard University Press.

Goldman, A. I. (1992). Epistemic folkways and scientific epistemology. In Liaisons. Philosophy meets the cognitive and social sciences, Cambridge MA: A Bradford Book.

Hookway, C. (2008). Peirce and skepticism. In J. Greco (Ed.), The Oxford handbook of skepticism (pp. 310-329). Oxford: Oxford University Press.

Ingarden, R. (Ed.). (1971). O niebezpieczeństwie petitionis principii w teorii poznania [On the Danger of Petitio Principii in the Theory of Knowledge]. In $U$ podstaw teorii poznania [The Foundation for Theory of Knowledge], pp. 357-380. Warszawa: PWN.

Peirce, C. S. (1931-58). Collected papers, t. 1-8. Cambridge: Harvard University Press (quoted as CP).

Quine, W. V. (1969). Ontological relativity and other essays. New York and London: Columbia University Press.

Sextus, E. (2000). Outlines of scepticism (J. Annas \& J. Barnes, Trans.). Cambridge and New York: Cambridge University Press.

Stępień, A. B. (1966). O metodzie teorii poznania [On Method in the Theory of Knowledge]. Lublin: TN KUL.

Unger, P. (1975). Ignorance. A case for scepticism. Oxford: Clarendon Press.

Williams, M. (2001). Problems of knowledge. A critical introduction to epistemology. Oxford: Oxford University Press.

Wiśniewski, A. (1992). Sceptycyzm a kryterium prawdy [Skepticism and the Criterion of Truth]. Poznańskie Studia z Filozofii Nauki, 12, 173-190.

Woleński, J. (1995). On Ajdukiewicz's Refutation of Scepticism. In V. Sinisi \& J. Woleński (Eds.), The heritage of Kazimierz Ajdukiewicz. Amsterdam, Atlanta: Rodopi. "Poznań Studies in the Philosophy of the Sciences and the Humanities" 1995 vol. 40, pp. 353-356.

Ziemińska, R. (1993). Intuicja przeżywania [Pre-introspective Self-Consciousness] Przeglad Filozoficzny Nowa Seria, vol. 2, no. 2, pp. 71-87.

Ziemińska, R. (2002). Eksternalizm we wspótczesnej epistemologii [Externalism in Contemporary Epistemology]. Szczecin: WNUS.

Ziemińska, R. (2013a). Historia sceptycyzmu. W poszukiwaniu spójności [History of Skepticism. In Search of Consistency]. Toruń: UMK.

Ziemińska, R. (2013b). Pragmatic Inconsistency of Sextan Skepticism. Polish Journal of Philosophy, 7(1), 71-86. 